\title{
立方晶フェライト焼結体の高温加圧変形
}

\author{
西川友三・西田俊彦・石川 誠・上柿利勝 -上井 勲 \\ (京都工芸繊維大学 工業化学教室)
}

\section{Hot Forging of Cubic Polycrystalline Ferrite}

By

\author{
Tomozo NISHIKAWA, Toshihiko NISHIDA, Makoto ISHIKAWA, Toshikatsu \\ UEGAKI and Isao UEI \\ (Department of Chemistry, Kyoto Institute of Technology)
}

\begin{abstract}
Cubic polycrystalline Ni-Zn ferrite was hot-worked at $1300^{\circ}$ to $1470^{\circ} \mathrm{C}$ and at stresses of 160 to $480 \mathrm{~kg} / \mathrm{cm}^{2}$ using a press forging technique. The ferrite deformed easily at higher temperatures than $1400^{\circ} \mathrm{C}$. However, as expected, grain elongation and orientation of cubic polycrystalline ferrite during hot forging were much harder than hexagonal polycrystalline ferrite. On the other hand, nonuniform microstructures in a forged sample were usually obtained, because of a severe shear strain gradient during deformation. The microscopic observation of outer surface of the forged sample showed that dislocation movement within the grains had much contribution to plastic deformation of the cubic polycrystalline ferrite. And this provided a possibility for controlling the microstructure of cubic polycrystalline ferrite by hot forging.
\end{abstract}

[Received September 17, 1973]

\section{1. 緒言}

近年, いろいろな種類のセラミックスが, ホットプレ スで作られるよらになった. また，ホットプレスの際の 緻密化の機構についても, 数多くの研究がなされてき た。たしかに, 適当な条件を選んで, ホットプレスを行 ならと, その緻密化の機構は, C. Herring ${ }^{1)}$ のうな, 加圧によって促進された拡散機構によって説明される が, それでもなお, 出来上ったホットプレス焼結体の顕 微鏡組織の観察は, ホットプレス中に結晶粒子の成長が 起ったこと，個々の結晶粒子が，ある特定の結晶軸方向 へ配向したといらことを示す.一方，クリープのような 多結晶体の高温変形に関する研究から ${ }^{2), 31}$ は, ホットプ レス中の緻密化には，単に加圧によって促進された拡散 だけでなく, 粒界のすべりや, とくに, 転位の移動など の寄与も大きく関係していることが分っている. そのら え, これらの結晶粒子成長や結晶粒子の配向, 結晶粒子 内での転位の移動というものは，ホットプレス中に，そ れぞれ独立して起るむのではなくて，相互に関係しあっ て起るものであろらということも推察がついてきた。 た，これらの起る程度が，ホットプレス焼結体中に残る 歪の量, したがって, ホットプレス焼結体の機械的性質 にも影響を与えるであろうし，また，結晶粒子成長や結 晶粒子の特定の結晶軸方向への配向の問題は, 燒結体に
単結晶に近い性質を与えうる可能性（焼結体内の各結晶 粒子の特定の結晶軸方向への配向は，多結晶体でありな がら，全体としての結晶軸が揃らことになるので）を持 つので, 機械的性質のほかに, ここで対象としているフ ェライト焼結体のような場合には, その磁気的性質の改 良にも，大きい影響を与えることになる．著者らは，さ きに, 六方晶フェライト焼結体の高温変形時における結 晶粒子の配向の問題について報告した ${ }^{4)}$. 六方晶フェラ イト焼結体の結晶粒子は,ふつうの焼成に際しても, $c$ 面 が発達しやすく, 平板状の結晶粒子になりやすい傾向を 持つので, 圧力下での高温変形ではさらにその傾向が顕 著となり, 結晶粒子成長や配向の観察は比較的容易であ った.この論文では，加圧下で立方晶フェライト焼結体 を高温変形させたときに，顕微鏡組織的にどのような変 化が起るかといらことについて調べた結果について報告 する.もちろん，六方晶フェライト焼結体で観察された ような各結晶粒子の伸長や加圧方向に垂直な方向への $(00 l)$ 面の配向のようなことは, 立方晶フェライト燒結 体では起りにくいことが予測されるが, $\mathrm{MgO}$ の hot extrusion や press forge において, 多結晶体中の結晶 粒子の伸長が観察されているので5), 立方晶フェライト 焼結体においても, その可能性はないことはないと考え t. 


\section{2. 実験 方 法}

立方晶フェライト焼結体としては, 最も一般的なフェ ライトとして, $\mathrm{Ni}_{0.5} \mathrm{Zn}_{0.5} \mathrm{Fe}_{2} \mathrm{O}_{4}$ の組成の $\mathrm{Ni}-\mathrm{Zn}$ フェ ライト焼結体を選んだ.フェライト焼結体は， $\mathrm{NiO}$, $\mathrm{ZnO}, \mathrm{Fe}_{2} \mathrm{O}_{3}$ を，モル比で 1:1:2 の割合で湿式混合 した原料を， $1000^{\circ} \mathrm{C}$ で 2 時間炍燒したのち，空気中で $1250^{\circ} \mathrm{C}, 2$ 時間, 焼成して作った. 焼結体の気孔率は, ほぼ 95\% から 97\% の閒であった。焼結体試料は，ダ イアモンドカッターで, 断面積 $10 \times 10 \mathrm{~mm}$ に切り出 し，変形が表面の瑕の影響をうけないように，表面は鏡 面にまでダイアモンドペーストで研磨して㧈いた。

高温加圧変形用の装置の概略を図-1 に示す. 加圧は 静的に一定荷重を加えた。変形用試料の.上下には，スペ 一サーとして，ホットプレスアルミナを挿入し，その上 下から炭化珪素の焼結体の棒で加圧した，炉の発熱体は 内径 $50 \mathrm{~mm} \phi$ の炭化珪素管で, 発熱体と試料や荷重棒 との間には，発熱体と変形試料の接触を防ぐために，ア ルミナ管を挿入したまた，変形量は，差動トランスを 用いて測定した。

\section{3. 実駼結果と考察}

変形の際のいろいろな実際の条件は, 表-1 に示す通 りであるが，測定温度範囲は $1300^{\circ} \sim 1470^{\circ} \mathrm{C}$, 加圧力範

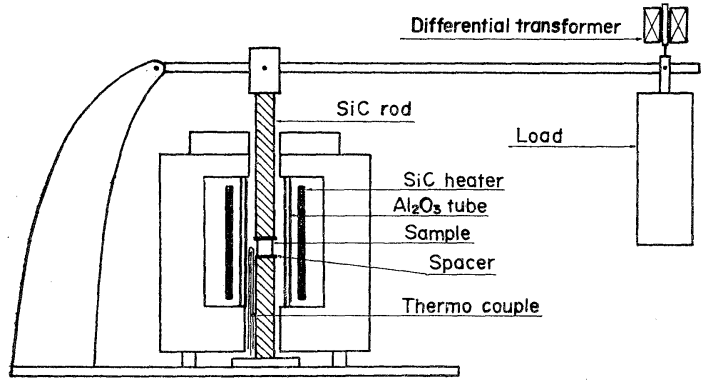

Fig. 1. Apparatus for hot forging.

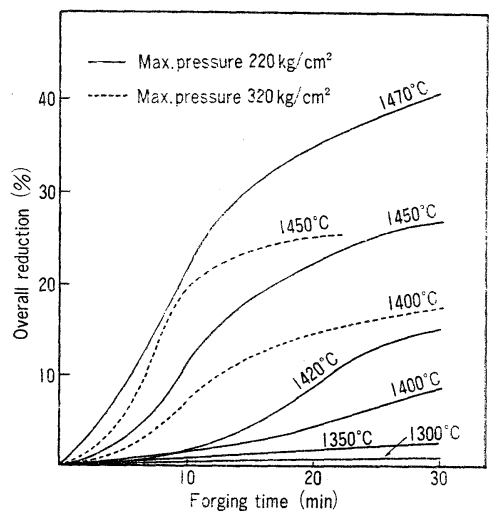

Fig. 2. Time dependence of overall reduction in hot forging of polycrystalline $\mathrm{Ni}_{0.5} \mathrm{Zn}_{0.5} \mathrm{Fe}_{2} \mathrm{O}_{4}$.

囲は $160 \sim 480 \mathrm{~kg} / \mathrm{cm}^{2}$, 加圧時間は 10 120 分の範囲で あった. 図-2 は, 加圧変形中の高さの減少率（表-1の 説明の部分参照)一時間曲線を, 加圧力 $220 \mathrm{~kg} / \mathrm{cm}^{2}$ 之 $320 \mathrm{~kg} / \mathrm{cm}^{2}$ の場合について，差動トランスを通して測 定した結果を示したものである. 図からも分るように， $1400^{\circ} \mathrm{C}$ 以上になると, $1350^{\circ} \mathrm{C}$ 前後の温度にくらべて, 変形が急に容易になる。図-3 法, Ni-Zn フェライト焼 結体を，高さの減少率 $45 \%$ 位まで変形させた時の，変 形前後における形を示したものである.図-3 の左上は， 変形前の試料を上から見をところ, 右上は変形後の同じ 試料を上から見たところであり，左下は変形前の試料を 真横から, 右下は変形後の試料をやはり真横から見をも のである. 立方晶フェライト焼結体は, 六方晶フェライ 卜焼結体にくらべて変形しにくいとは，一般に考えられ 勝ちであるが，それでも，高さの減少率が $50 \%$ くらい までは,あまり大きい割れを発生することなく変形した。

これらの焼結体の加圧下での高温変形には, ホットプ レスの場合も同様であるように，結晶粒子の成脣や配向 がともなう。したがって，これらの高温変形を，ただ外

Table 1. Conditions for forging of polycrystalline $\mathrm{Ni}_{0.5} \mathrm{Zn}_{0.5} \mathrm{Fe}_{2} \mathrm{O}_{4}$ ferrite.

\begin{tabular}{|c|c|c|c|c|c|c|c|}
\hline $\begin{array}{l}\text { Forging temp. } \\
\qquad\left[{ }^{\circ} \mathrm{C}\right]\end{array}$ & $\begin{array}{c}\text { Max. press. } \\
{\left[\mathrm{kg} / \mathrm{cm}^{2}\right]}\end{array}$ & $\begin{array}{l}\text { Forging time } \\
\qquad[\mathrm{min}]\end{array}$ & $\begin{array}{l}\text { Starting ht. } \\
{[\mathrm{mm}]}\end{array}$ & $\begin{array}{l}\text { Ht. after forging } \\
\qquad[\mathrm{mm}]\end{array}$ & $\begin{array}{l}\text { Overall reduction } \\
{[\%]}\end{array}$ & $\begin{array}{l}\text { Max. negative } \\
\text { true strain }\end{array}$ & $\begin{array}{c}\text { Ave. strain rate } \\
{[\dot{\varepsilon} / \mathrm{min}]}\end{array}$ \\
\hline 1300 & 160 & 10 & 3.90 & 3.89 & 0.3 & 0.004 & 0.0004 \\
\hline 1350 & 160 & 10 & 3.53 & 3.51 & 0.6 & 0.006 & 0.0006 \\
\hline 1350 & 320 & 10 & 4.0 & 3.8 & 5.0 & 0.049 & 0.0049 \\
\hline 1400 & 320 & 10 & 4.0 & 3.8 & 5.0 & 0.049 & 0.0049 \\
\hline 1400 & 320 & 60 & 4.0 & 2.7 & 32.5 & 0.39 & 0.0065 \\
\hline 1400 & 320 & 120 & 3.9 & 2.8 & 28.2 & 0.32 & 0.0027 \\
\hline 1400 & 480 & 70 & 4.1 & 2.7 & 34.1 & 0.41 & 0.0056 \\
\hline 1300 & 220 & 120 & 7.5 & 7.1 & 5.3 & 0.005 & 0.00004 \\
\hline 1350 & 220 & 120 & 7.4 & 6.2 & 16.2 & 0.17 & 0.0014 \\
\hline 1400 & 220 & 60 & 6.8 & 3.8 & 44.1 & 0.56 & 0.0093 \\
\hline 1420 & 220 & 50 & 7.2 & 4.5 & 37.5 & 0.48 & 0.0096 \\
\hline 1400 & 320 & 50 & 8.6 & 5.0 & 41.9 & 0.55 & 0.011 \\
\hline 1450 & 320 & 40 & 8.5 & 5.0 & 41.2 & 0.53 & 0.013 \\
\hline 1470 & 320 & 40 & 8.6 & 4.7 & 45.3 & 0.60 & 0.015 \\
\hline
\end{tabular}




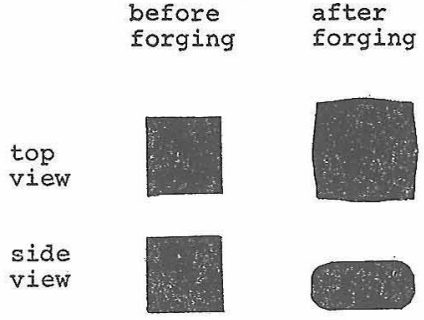

Fig. 3. Polycrystalline $\mathrm{Ni}_{0.5} \mathrm{Zn}_{0.5} \mathrm{Fe}_{2} \mathrm{O}_{4}$ before and after hot forging of overall reduction of $45 \%$.

形の変化だけでとらえるのではなく、変形量とともに焼 結体の顕微鏡的組織が，どの上うに変わるが調べるこ とは興味めることである。

図-4は，高さの隇少率が 45\%になるまで，変形させ たときの， Ni-Zn フェライト焼結体の加圧方向に平行 な面と，垂直な面の顕微鏡写真である. 六方晶の $\mathrm{Ba}$ フェライト焼絬体では，この程度の大きさの変形量で， 結晶粒子が伸長することが観察されたが4)，この立方晶 の Ni-Zn フェライト焼結体では，そのようなことは観 察されない。しかし，図-5に示した写真のように，高温 変形中に試料が破壞し，焼結体内にマク口な空間が生じ たような場合には，緻密な焼結体内部之ちがって，各々 の結晶粒子について，自由に変形しうる空閒が存在する ことになるので，その空闇を利用しての結晶粒子の伸長 が観察される。したがって，立方晶フェライト焼結体に ついても, 結晶粒子の伸長は,必ずしも不可能ではない。

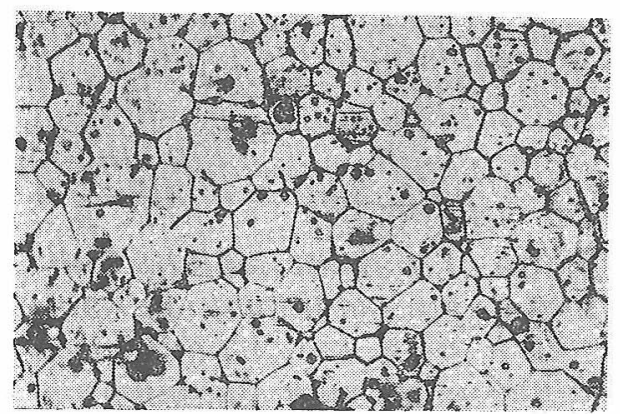

(a) perpendicular to forging direction

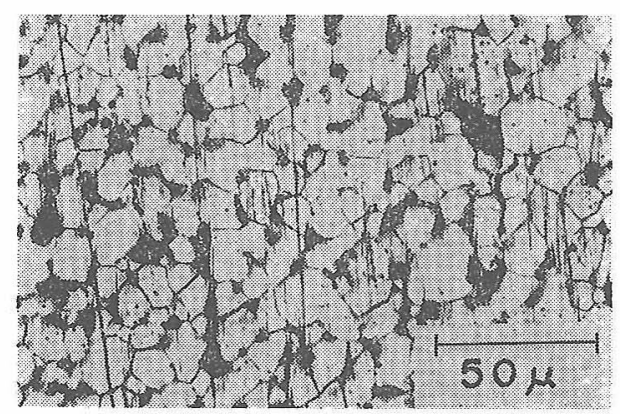

(b) parallel to forging direction

Fig. 4. Microstructure of hot forged polycrystalline $\mathrm{Ni}_{0.5} \mathrm{Zn}_{0.5} \mathrm{Fe}_{2} \mathrm{O}_{4}$.

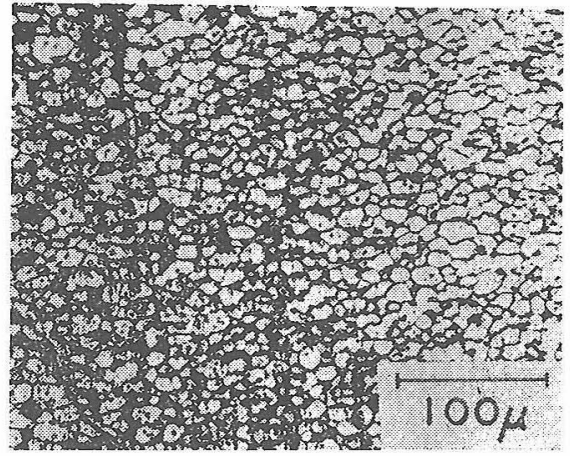

Fig. 5. Grain elongation of polycrystalline $\mathrm{Ni}-\mathrm{Zn}_{\mathrm{n}}$ ferrite along small cracks.

また，六方晶 $\mathrm{Ba}$ フェライト焼結体の高温変形こつい

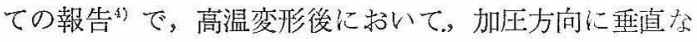
焼結体表面加らのX線反射は， $(00 l)$ 面加らの反射強度 が増加し，(hkl）面汃らの反射強度が減少することを述 べたが，立方晶の $\mathrm{Ni}-\mathrm{Zn}$ フェライト焼結体では，元の ようなことも起り難いようで岁った。图一6 はその事情 を示吉，図-6の（a）はふつらの焼結体の表面加らのX 線回折線図，(b) は高さの減少率 45\% まで変形させた のちの加圧方向に垂直な面汃らの，(c) は同心゙試料の平 行な面からのX線回折線図であるが，それらの間には， ほとんど差がなく，結晶粒子の配向が起らなかったこと を示している.

図-7 は, やはり高さの減少率 $45 \%$ をで変形させた特 の，焼結体断面の顕微鏡写真で劣る。（a）ほ燒結体の中 心部, (c) は燒結体の外周辺部にち汃ところ, (b) はそ の中間的位置に括ける焼結体の顕微鏡組織でるる。焼結 体の中心部に抺ける結昆粒子の大きさは，変形前の犬き さに等しいものであるが，試料の外周辺部に向らにつれ て, 中闑的な位置では結晶粒子の成長が, さらに外側で は，結晶粒子の微細化が観察された。これは変形蓄置の 関係で，焼結体詿料の中央部では変形量が小さく，外周 辺部になるほど，大きい倠形をうけることに由来するも

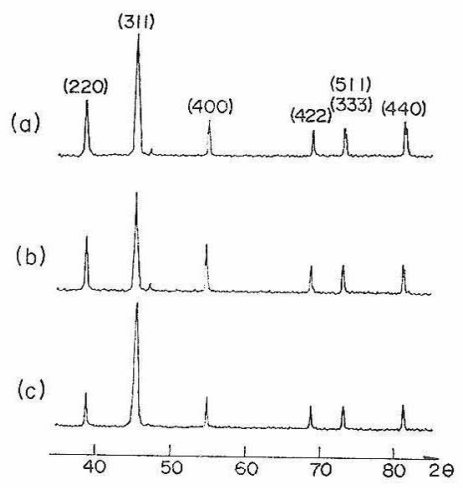

(a) non-oriented, (b) after forging (perpendicular to forging direction), (c) after forging (parallel to forging direction)

Fig. 6. X-ray diffraction patterns of non-oriented and forged polycrystalline $\mathrm{Ni}_{0.5} \mathrm{Zn}_{0.5} \mathrm{Fe}_{2} \mathrm{O}_{4}$. 


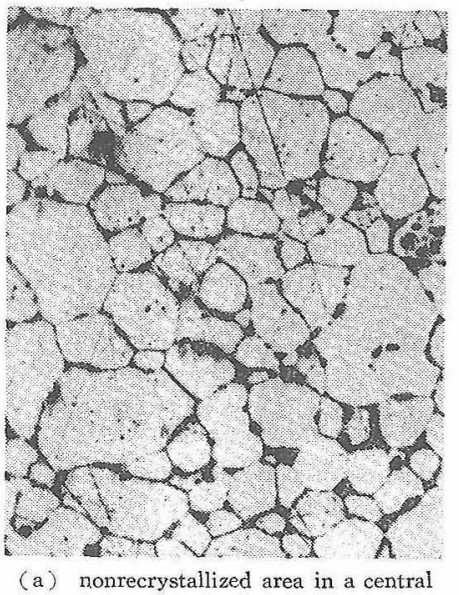

portion of the forged polycrystal

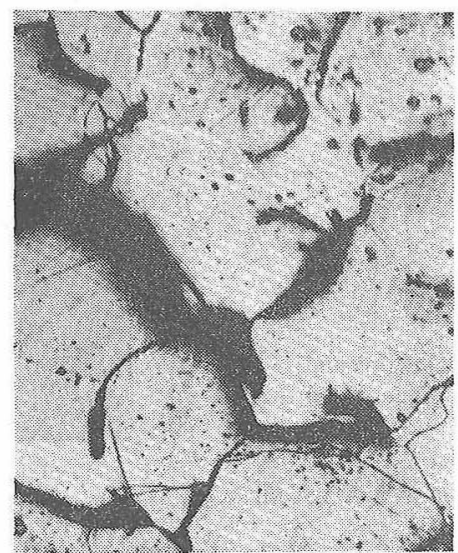

(b) large grains by grain growth in an intervening portion

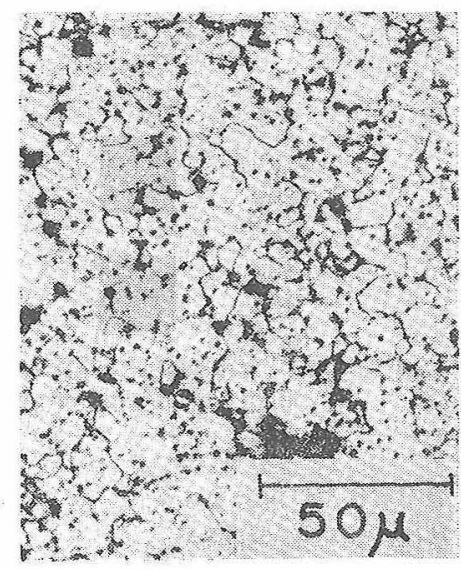

(c) fine grained recrystallized structure in an outer portion

Fig. 7. Microstructure of polycrystalline $\mathrm{Ni}_{0.5} \mathrm{Z}_{\mathrm{n}_{0.5}} \mathrm{Fe}_{2} \mathrm{O}_{4}$ of overall reduction of $45 \%$.

のであろう。すなわち，焼結体の中央部と外周辺部との 中間部分に乱いては，適当な量の変形によって，粒界近

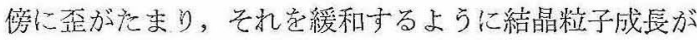
起る。外周辺部では，中間部分におけ忟るより，さらに大 きい显の変形をうけるので，粒子成長して大きくなった 絬晶粒子内での，転位の移動の量が增大し，粒界や転位 の移動党さまたげる場所に䎐位がたなる結果となりそ れらがさらにポリゴン化を起して，結晶粒子り微細化に 導くといらことが起ったのであるう。この現象と同様の ことは，アルミナ焼結体の hot working の研究に挨い

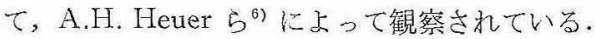

つぎに，変形した焼結体試料の 1 番外側の䒾面の顕微 鏡観察結果について述べる. それは，1番外側の表面で は，すべり率の観察が容易であるからである。すなわ ち, 溹結体内部では，たとえ，転位が移動してすべりが 起ったとしても，そのすべりが結晶粒界にさまたげられ て，大きいすべりに発達しにくく，したがって，顕微鏡 的には観察されにくいが，烇結体の 1 番外側の表面で は，繀晶粒界のように，す心゙りをさまたげるものはない ので、ナべり帯が,外側の自由表面で大きいものに発達し やすく，そのため，顕北鏡観察の刘象になりやすいから である。図-8に惊，Ni-Zn フェライト焼結体の自由表

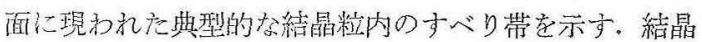
粒內にす心゙りが起る，換言すると，結晶粒子内で転位が 動く,あるいは,転位の移動によって塑性変形が起るとい うことは，立方晶フェライト燒結体の場合です充分起り らることである。図-9 惊さの減少率が $5 \%$ 程度の変 形焼絬体の外表面の顕微鏡写蒖である。先に，図-8 で 示したようなすべりというものは，5\%くらいの減少率 のところでは，まだほとんど観察されない。ただ，同じ 5\%くらいの減少率の場合でも，烍結体中に，むし大き い結晶䊀子が存在すると，図-10のよらに，こまかいす ベり燕が観察される. 図-11 沙減少率が大きくなって,

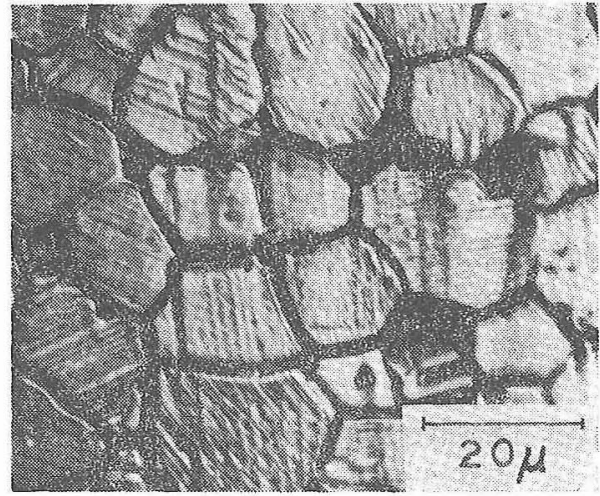

Fig. 8. Typical slip bands in polycrystalline grains of $\mathrm{Ni}-\mathrm{Zn}$ ferrite.

$25 \%$ くいになった場合の焼結体の外表面の顕微鏡写 真である、すべり苧の観察される粒子の数が，増加して きていることが分る．このようなすべり带を電子顕微鏡 で見ると，こまかい沃山のすべりのあとが，図-12 のよ らに見られる，また，变形前に燒結体表面を鏡面にまで 研磨するとき，表面上に，研磨硅粒による㩔あとがのこ ったとすると, 変形後, 図-13のように，その部分では ず゙りが起らない（すべり帯の生じていない部分，すな

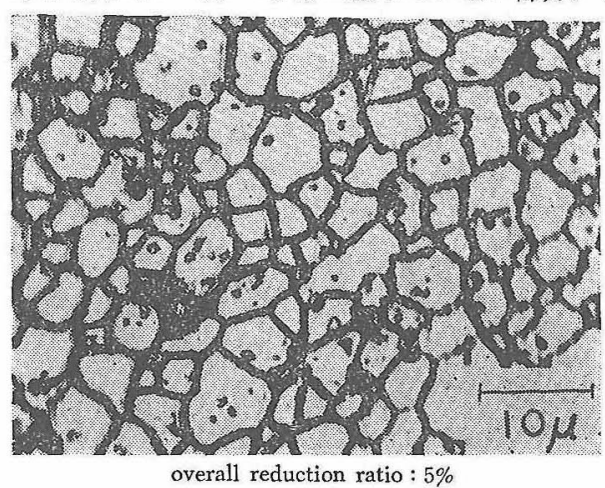

Fig. 9. Microstructure of outer surface of hot forged polycrystalline $\mathrm{Ni}_{0.3} \mathrm{Zn}_{0.5} \mathrm{Fe}_{2} \mathrm{O}_{4}$. 
わち,すべり帯の間にあるぶつぶつの観察される部分 が，研磨の概あとである)。すなわち，この部分では， すべりの行なわれることが困難になって, 加工硬化に相 当する現象が起ったことを示すこの研磨の珢あとであ るすべりの起りにくい部分は，もっと高温になっても， やはりすべりが起りにくく，高温での変形では，図-14 のようになる。図-15 は, 高さの減少率がさらに大きく， 約 $35 \%$ の場合の焼結体の外表面の䡛微鏡写真である。 この場合は, 減少率が小さい場合とちがって，図-15で は，やや観察しにくいが，図-15 の一部老電子顕微鏡に とって拡大した図-16 で見られるように，転位のポリゴ ン化による再配列によって，結晶粒子が微細化しつつあ 当事情が分る. すなわち, 図-7 で, 焼結体の外周辺部 に近いところで，結晶粒子が微細化したことは，この図 -16 からも示されることになる。 またこのポリゴン化 による結晶粒子の微細化は， R.B. Day ら”の報告にあ るように，転位の移動による塑性変形によって，粒界に たまった転位が，ポリゴン化によって亜結晶粒子を作る という,マグネシアについての锁察と同じ現象が起った ことを教える。

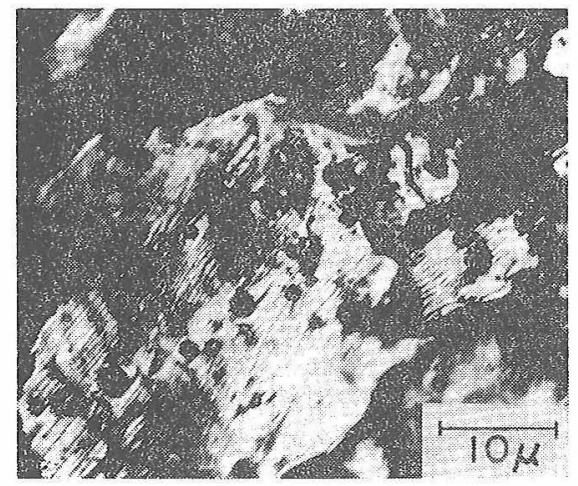

overall reduction ratio; $5 \%$

Fig. 10. Fine slip band observed in the large grains of outer surface of hot forged polycrystalline $\mathrm{Ni}_{0.5} \mathrm{Zn}_{0.5} \mathrm{Fe}_{2} \mathrm{O}_{4}$.

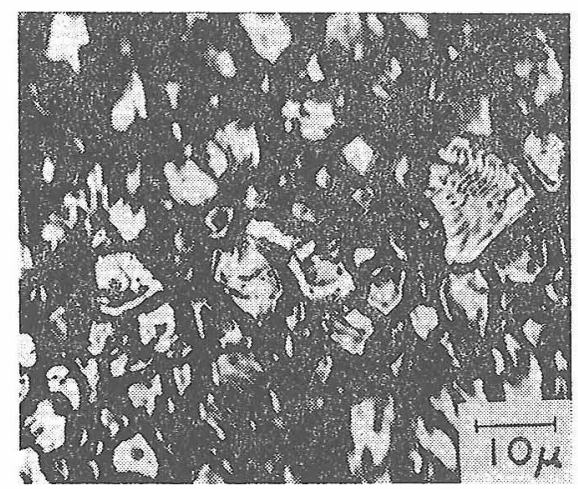

overall reduction ratio; $25 \%$

Fig. 11. Microstricture of outer surface of hot forged polycrystalline $\mathrm{Ni}_{0.5} \mathrm{Zn}_{0.5} \mathrm{Fe}_{2} \mathrm{O}_{4}$.

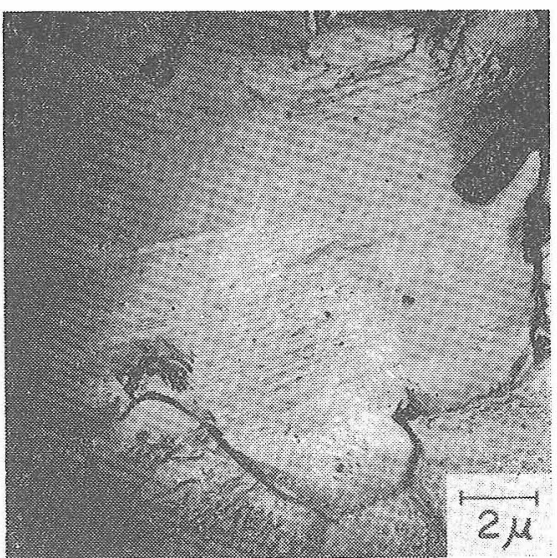

Fig. 12. Electron micrograph of slip bands in a grain of Fig. 11.

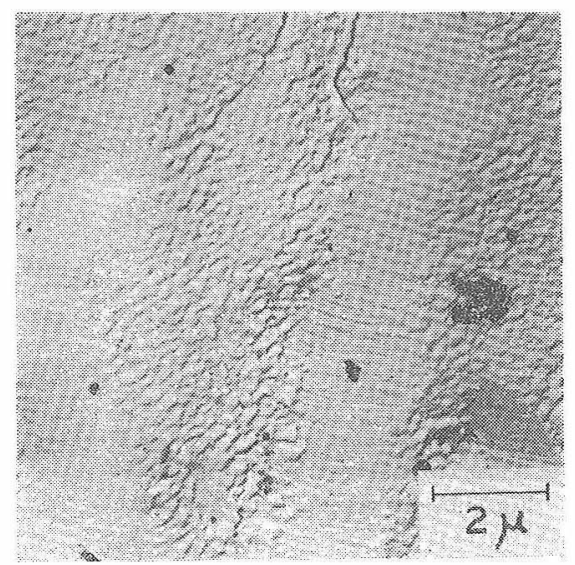

Fig. 13. Slip bands on a surface with scratch (the part of scratch had not slip band).

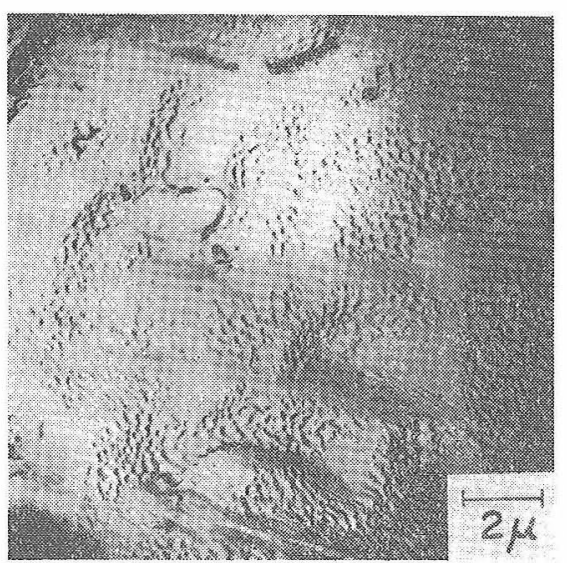

Fig. 14. Slip bands on a surface with scratch (the deformation temperature was higher than Fig. 13).

以上の钼察から，立方晶の Ni-Zn フェライト焼結体 で，転位の移動飞よる塑性変形が，充分起りらること が，証拠づけられたと思う。しかし，ふつううの顕微鏡観 察で転位による望性変形を看過し勝ちなのは，たとえ， 


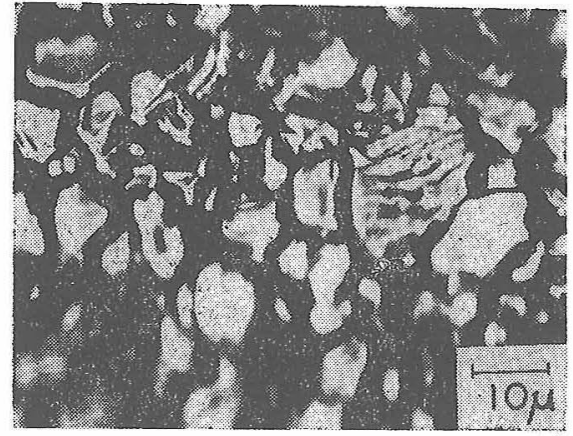

overall reduction ratio; $35 \%$

Fig. 15. Microstructure of outer surface of hot forged polycrystalline $\mathrm{Ni}_{0.5} \mathrm{Zn}_{0.5} \mathrm{Fe}_{2} \mathrm{O}_{4}$.

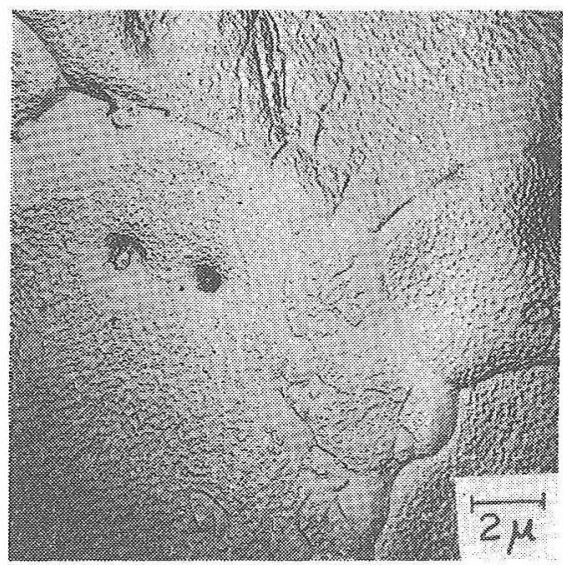

Fig. 16. Enlarged photograph of Fig. 15.

本位による塑性变形があったとしても，それが焼結体内 部では，結晶粒帠の上ころで止められ勝亏て，焼絬体の 外表面のように大き寺すべり量, あるい虫, 资形量にな らないためであると考えられる。図-17 法，筧結体内部 の気孔に近い部分の高湿峦形後の題微鏡写真であるが， この場合,気孔驻焼結体の外表面のように,結晶粒子が自

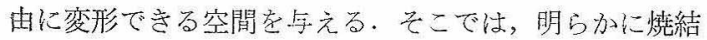

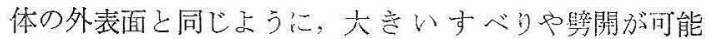
で，それらが起ったことが图-17 亿示されている。そし てまたここれら燒結体内部での割れの原图にもなる。

\section{4. 結言}

本研究は, 先の六方晶 $\mathrm{Ba}-$ フェライト焼絬体の商温変 形に関する研究しにつういて，六方晶フェライトの埸合 に見られたような，結晶粒子の伸長や配问汸，立方晶フ ェライトの高温変形の場合にも観察されるのかどうか （六方晶フェライトの容易さにくらべて，站劦晶フェラ イトの困難さが予想されるので，ま衣，立方晶フェラ イトの高温変形の機構について, 何らかの示唆がえられ ないだろらか，といらことを目的として行尖われた。結 果をまとめると，

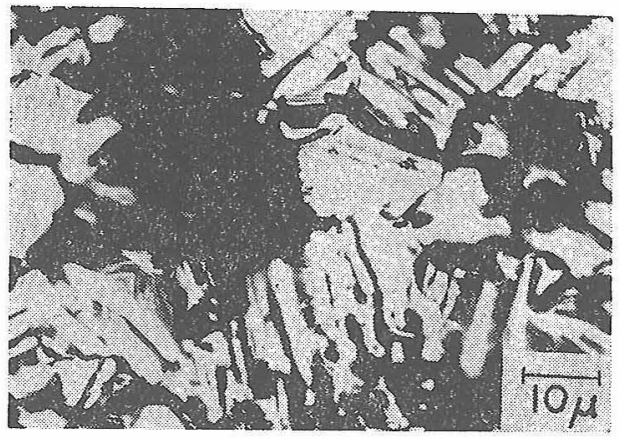

Fig. 17. Slip and crack in an area adjacent to a large pore.

1）立方晶 $\mathrm{Ni}-\mathrm{Zn}$ フェライト焼結体の圧力下での高 温変形心関する実験を，温度 $1300^{\circ} \sim 1470^{\circ} \mathrm{C}$, 压力 160 $\sim 480 \mathrm{~kg} / \mathrm{cm}^{2}$, 時間 10 120 分の䉇囲で行なったが，温 度の影響がもっとも大きく， $1400^{\circ} \mathrm{C}$ 以上の温度で変形 は容易であり，40 50 分以内滈さの減少率にして, $50 \%$ 程度にまで容易に変形した。

2）予想されたように，立方晶 $\mathrm{Ni}-\mathrm{Zn}$ フェライト焼 結体注，六方晶Ba一フライト焼結体の上うに，容易に 結晶粒子伸長したり，配问したりすることはなかった。 しかし，たとえば燒結体内の割れの近傍のよらに，変形 のための自由な空間が存在する場所では, 立方晶フェラ イトの場合でも粒子伸長の起りらることが観察された。

3）立方晶 $\mathrm{Ni}-\mathrm{Zn}$ フェライト焼結体の高温変形で は，C. Herring の圧力によって促進される搪散のよう な搪散橉棈のみによって変形が進行するのではなく, 転 位の移動による塑性変形の影響も, 温度や加圧の条件に よって，かなり著しくなってくることが示された。した がって, これらの条件の制御は, 微細構造の制御，ある いは，焼結体内部にたまる歪や割れの制御に関係し，そ の焼結体の機械的な性質だけでなく、フェライトの場合 には，宗の磁気的性質とも大きい関係をもってくるので， これらの性覧の改定のた放決非常に大事な手段上なる。

\section{文部}

1) C. Herring, J. Appl. Phys. 21 [5] 437-45 (1950).

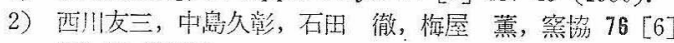
209-16 (1971)

3）西川友三，西因俊彦，岩本害三，生門博志，上井 勲， 案协 81 [5] 203-10 (1973).

4）、酉川友三，四田俊彦，井上清，井上英重，上井 勲， 筧協 82 [5] 241-47 (1974).

5) R.W. Rice, J.G. Hunt, G.I. Friedman, J.L. Sliney, Identifying optimum parameters of hot extrusion, Final Report for National Arronautics and Space Administration, Contract NAS 7-276, Aug. (1968).

6) A.H. Heuer, D.L. Sellers, W.H. Rhodes, J. Am. Ceram. Soc. 52 [9] 468-94 (1969).

7) R.B. Day, R.J. Stokes, ibid. 49 [7] 345-54 (1966). $(9 / 17 / 1973$ 受付) 